\title{
Factors Influencing Bank Profitability in a Developing Economy: Panel Evidence From Bangladesh
}

\author{
Saeed Sazzad Jeris, Shahjalal University of Science and Technology, Bangladesh
}

iD https://orcid.org/0000-0001-9656-385X

\begin{abstract}
The purpose of this paper is to investigate the bank-specific and macroeconomic determinants of commercial banks profitability operating in Bangladesh to explore the role of both internal and external factors in achieving high profitability. The fixed effect model is built on a balanced panel data set comprising 135 observations of 27 commercial banks over the period 2014-2018. Regression findings reveal that size and capital ratio are significant bank-specific determinants of bank profitability in Bangladesh where the effect of loans ratio is statistically insignificant. Findings also suggest that banks with higher deposits tend to be more profitable, and small banks have efficient management. The cost-to-income ratio and loan loss provisions are statistically insignificant on the performance of banks. On the other hand, macroeconomic variables such as GDP growth have a significant impact on profitability whereas the effects of inflation on profitability are statistically insignificant in some cases.
\end{abstract}

\section{KEYWORDS}

Bank-Specific, Banking Sector in Bangladesh, Banks, Determinants, Fixed Effect Model, Macroeconomic, Performance, Solvency

\section{INTRODUCTION}

Banks play a significant role in a country's' economic development and by converting deposits into productive investments, the banking sector provides financial intervention and economic stimulation. If a bank performs well, then it should record its profitability growth because it will indicate where the bank is now standing. Rajan \& Zingales (1995) stated that the growth of the economy will depend on the soundness of the banking sector. During the last couple of decades, the banking sector has experienced global serious changes in its operating context and the structure and performance of the banks have affected by both internal and external factors. According to Alunbas et al. (2001), as financial deregulation, technological, and financial innovation are becoming more challenging for market participants, financial institutions and banks should give more priority to their bank efficiency.

The word "profitability" indicates the capacity of a business institution to sustain its earnings season after season. The financial institutions' profitability represents the progress of the institution 
which is one of the investors' most powerful evaluation criteria. Profitability shifts are leading to economic growth as profits affect businesses' spending and savings strategies. Additionally, the increase in earnings increases the cash flow status of firms and generates significant stability in the path of investment portfolio funding. Easier external financing allows to focus more on increasing efficiency and productivity, also creates working opportunities (Menicucci \& Paolucci, 2016). Nevertheless, for maintaining the soundness of financial institutions in both present and future, factors affecting the profitability should be explored.

Many studies, for example, Short (1979), Bourke (1989), Molyneux \& Thorton (1992), and Goddard et al. (2004) have examined the sources of variables in bank-level profitability in finance and accounting, economics, and strategic management sector. However, these findings enable to conduct of a worthy analysis of bank profitability but in some areas, the issues are not dealt with sufficiently. Firstly, in many studies, the concept of econometric technology does not effectively explain which is not appropriate for some characteristics of bank profits. Meaning that the results obtained may be inconsistent and biased. In addition, the literature does not describe the effect of macroeconomic variables, used a small-time dimension of the panels. From most of the studies, it is found that bank performance is influenced by domestic factors.

This study tries to examine possible internal determinants of bank profitability of the Bangladeshi banking sector such as size, operating efficiency, liquidity, credit, market share. However, the impact of macroeconomic variables (GDP and inflation) on bank profitability is also considered. The findings of the study are likely to be essential to the policymakers, investors as well as the banking itself.

The paper is organized in the following manner. The next section presents the banking sector of Bangladesh. Section 3 reviews the relevant literature on the determinants of bank profitability followed by a description of the data and research methodology. Section 5 reports the findings of the study and the conclusion of the study is presented in section 6 .

\section{BANKING SECTOR OF BANGLADESH}

Bangladesh's economy is heavily reliant on the banking industry. The attainment of profitability is the one that will support the stability of the financial system. The banking industry offers a variety of financial services, including mortgages, long-term earnings, compensation, and loans to alleviate poverty. In order to contribute to this aspect, profitability is key for a bank. Bangladesh Bank took some actions when the national commission of money, credit, and banking recommendations changed the financial intermediation system. Despite the series of actions, the overall profitability has remained inconsistent. According to the IMF report, the state-owned commercial and specialized banks are facing various unavoidable problems like large capital shortfalls, low profitability, balance sheet weaknesses. In recent years, for recapitalizing the banks, the government has given a large amount of money. Pursuant to the data from the government's finance division, the government has provided state-owned banks with a total of TK 116.6 bn in recapitalization funds in 2016-17.

It is necessary to identify the factors that impact significantly on bank performance in Bangladesh. In this context, some studies have occurred to find out the variables for the profitability of the banking sector, for instance, size has a negative relation with ROA (return on asset) and NIM (net interest margin) while exhibits opposite result to return on equity (Sufian, 2009). In fact, the operating or earning performance varies from bank to bank as there is a difference in their structure and location, size, liability composition, and asset portfolios. Some banks achieve high rates of return, while others gain lower ones. Many studies have been explained the sources of mutation, but few researchers tried to find out the determinants of profitability of the banking sector in Bangladesh. Macroeconomic variables are also playing a significant role in the performance of banks. However, the effects of external determinants such as GDP, inflation rate on banks' profitability is still inconclusive in Bangladesh. Some studies found a significant relationship between profitability and macroeconomic variables, while few researchers also did not find that. The aim of this paper is to find out the factors 
related to the profitability of Bangladeshi banks. By following widespread literature, we have included a set of internal variables in our regression model to see their effects on banks' performance. Along with domestic variables, we also take some macroeconomic variables, such as GDP, inflation rate to capture their effects on overall performance.

\section{LITERATURE REVIEW}

The factors related to the bank's profitability are composed of bank-specific characteristics and macroeconomic determinants. The internal determinants could be entitled bank-specific or micro factor profitability where the external determinants include economic growth, inflation, and financial crisis that are not associated with bank management but affect the economic and legal environment.

The exploration undertaken has focused on profitability analysis of either country-specific or a panel of the country's banking system. One group of researchers include Berger et al. (1987), Goddard et al. (2004), Naceur \& Goaied (2001), Neely \& Wheelock (1997), Athanasoglou et al. (2008), and Batten \& Vo (2019). The other group of studies involves Demirguc-Kunt \& Huizinga (1999), Angbazo (1997), Short (1979), Abreu \& Mendes (2001), Bourke (1989), Adelopo et al. (2018) explored the factors of bank profitability in a panel of countries. They found there is a notable relationship between ROE and interest rate, inflation rate, and government ownership.

The internal determinants of bank profitability could also be termed micro factors that expose the differences in bank size, capital ratio, capital adequacy, liquidity, loans, and deposits. According to Akhavein et al. (1997) and Smirlock (1985), the relationship between size and profitability is positive and significant. Demirguc-Kunt \& Huizinga (1999) documented that the factors related to the financial and legal affect bank productivity are closely associated with firm size. On the other hand, Batten \& Vo (2019) found a negative association between bank size and profitability. Meanwhile, Short (1979), Haslem (1968), Molyneux \& Thorton (1992), Bikker \& Hu (2002), and Goddard et al. (2004) linked firm size with capital ratios.

Among many reasons for bank failure, poor asset quality, and low levels of liquidity are also considered in the literature and in the time of uncertainty, the financial institutions may diversify their portfolio to reduce the amount of risk. According to Molyneux \& Thorton (1992), there is a negative and significant relationship between the level of liquidity and profitability while Bourke (1989) stated the opposite findings. This result may be defined that financial institutions are exposed to high-risk loans, meaning that these loan losses have contributed to lower returns. Additionally, Miller \& Noulas (1997) noted that the effect of credit risk on the portfolio is clearly negative. Hess and Francis (2004) found that the cost-income ratio and profitability of the bank are inverse. In addition, Ghosh et al. (2003) also pointed out the anticipated adverse relation between the cost-income ratio and the efficiency ratio. However, Hassan \& Bashir (2003) found a positive relationship between operating the cost-income ratio and profitability. In a recent paper, Adelopo et al. (2018) stated that size, cost management, and liquidity have a strong association with bank profitability. Also, Batten \& Vo (2019) evident that capital adequacy, risk, productivity, and expense influence the banks' performance.

The second type of determinants is the external factors where economic growth, inflation, interest rates, and cyclical output were examined. Revell (1979) argued that if the banks' wages and other operating expenses rise at a faster rate than inflation then there will be an effect of inflation on bank profitability. According to Staikouras \& Wood (2004), inflation may have both direct and indirect effects on the efficiency of banks. The studies by Bourke (1989) and Molyneux \& Thorton (1992) pointed out that there is a positive relationship between inflation and profitability. Another important macroeconomic condition that may affect both the costs and revenues of banks is a gross domestic product. Berger et al. (1987) mentioned that GDP (gross domestic product) growth rate reflects several variables related to the supply and demand for loans and deposits. Recently, Adelopo et al. (2018) examined the relation between bank-specific, macroeconomic factors, and bank performance and found that macroeconomic factors also have a strong impact on banks' profitability before and after the 
financial crisis. Furthermore, Batten \& Vo (2019) also mentioned the importance of macroeconomic factors on bank profitability in Vietnam.

\section{DATA AND METHODOLOGY}

\section{Data and Sample}

This study has gathered data from the annual report of 27 Bangladeshi commercial banks in the period of 2014 to 2018. Banks and variables are selected based on the availability of the data and the prior literature. Table 1 represents the variables used in this study. ROA and ROE represent the banks' profitability. Bank-specific variables include size, cost to income ratio, capital ratio, loan ratio, deposits, loan loss provisions, and market share of banks where GDP and inflation have considered as macroeconomic variables. The data of macroeconomic variables are extracted from the World Bank.

\section{Variable Description}

This section describes the variables used in this study. Also, prior studies investigated the connection between independent variables and dependent variables are also described.

\section{Dependent Variables}

ROA (Return on Assets) and ROE (Return on Equity) are used as a measure of profitability. ROA reflects a banks' management ability to generate revenues by using banks' financial and investment resources (Hassan \& Bashir, 2003). To exemplify, Rivard \& Thomas (1997) mentioned that ROA is an indicator in which a bank manager can make a profit from banks' financial assets and real assets. On the other hand, ROE indicates how well bank management is in using shareholders' funds and it is calculated as net income after tax divided by the shareholders' equity.

Table 1. Variables used in this study

\begin{tabular}{|l|l|l|}
\hline \multicolumn{1}{|c|}{ Variable } & \multicolumn{1}{c|}{ Measure } \\
\hline Dependent variables & Return on assets & Net income/Average total asset (\%) \\
\hline ROA & Return on equity & Net income/Average total equity (\%) \\
\hline ROE & Independent variables $($ Bank-specific variables) & Log of total assets \\
\hline SIZE & Bank size & Operating expenses/Operating income \\
\hline CIR & Cost to income ratio & Equity/Total assets \\
\hline CAP & Capital ratio & Net loans/Total assets \\
\hline LOAN & Loan ratio & Total deposits/Total assets \\
\hline DEP & Deposits & Loan loss reserve/Total gross loans \\
\hline LLP & Loan loss provisions & Log of total deposits \\
\hline LNDEPO & Market share & \multicolumn{2}{|l}{} \\
\hline Independent variables $($ Macro-economic variables) & Annual real GDP growth rate \\
\hline GDP & Economic activity & Annual inflation rate \\
\hline INFLATION & Inflation
\end{tabular}




\section{Independent Variables}

For determining the bank's profitability, independent variables are used in this study and explained below:

\section{SIZE- Bank Size}

The total assets of the bank are used as a proxy for bank size and it is represented by the logarithm of total assets. The relationship between size and profitability could be positive if there are significant economies of scale (Akhavein et al., 1997; Bourke, 1989; Molyneux $\&$ Thorton, 1992). If increased diversification leads to lower credit risk, then the relevance could be negative. Also, other researchers found a negative relationship between profitability and bank size and this result is suggested by Miller \& Noulas (1997), Jiang et al. (2003), and Bashir (2003). However, Ben Naucer (2003) claimed that the size has a negative and significant influence mostly on net interest margins.

\section{CIR- Cost to Income Ratio}

The cost to income ratio is considered as the proxy of a bank's operational efficiency. Pasiouras \& Kosmidou (2007) got a negative relation between the cost to income ratio and profitability where Hassan \& Bashir (2003) found a positive relationship between cost to income ratio and profitability. However, the nexus between the cost to income ratio and profitability level is expected to negative.

\section{CAP- Capital Ratio}

The capital ratio is measured by equity over total assets and it represents the bank capitalization or capital adequacy as well as reflects the overall well-being and soundness of the bank. Bourke (1989) found a significant positive relation between capital adequacy and profitability in his study on the determinants of banks' performance for 12 countries selected from Europe, North America, and Australia. Similarly, most other studies that use capital ratio as an explanatory variable of bank profitability stated a positive relationship between the capital and profitability (Sufian \& Chong, 2008). However, Saona (2011) mentioned that it should be expected that banks with lower capital ratios have higher profits compared to well-capitalized financial institutions.

\section{LOAN- Loan Ratio}

Loan ratio (net loans/total assets) is used as a measure of liquidity risk which is considered an important determinant of bank profitability. The impact of the number of total loans on bank performance is very difficult to predict. Fast growth in the number of loans may also cause a decrease in the quality of credit and thus decrease income. If the bank raised loan volume through lower margins, it could be assumed a negative effect on profitability. Abreu \& Mendes (2002) revealed a positive relationship between loan ratio and profitability while Hassan \& Bashir (2003) noted that a higher loan ratio really influences profitability negatively.

\section{DEP- Deposit Ratio}

The deposits-to-total assets ratio (DEP) refers to the influence of deposits on performance. Banks depend heavily on customer deposits and the more deposits a bank gets, the more loans it can give to customers and thus produce more profit. Lee \& Hsieh (2013) has shown that additional savings can help banks in generating more income while low deposits can adversely affect their profitability. Being the main source of funding for banks, it could be expected that higher growing deposits would be able to expand the business of the bank and consequently generate more profits. So, it is expected to have a positive impact on banks' profits. 


\section{LLP- Loan Loss Provisions Ratio}

To assess the quality of the banks' assets, LLP (loan loss reserve/total gross loan) is used. The ratio is used as an independent factor to see how the earnings of Bangladeshi banks impact asset quality. A higher amount of allowance for loan loss suggests a lower credit quality and therefore lower profitability. Bad loans are expected to reduce profitability and a negative impact of loan loss reserves on bank profitability would suggest a reduced quality of loans that raise the provisioning costs and declines interest revenue. Thus, this ratio is expected to have a negative relationship with bank profitability. Miller \& Noulas (1997) noted that there is a negative relationship between credit risk and profitability. According to Golin (2001), the challenge for a bank is to minimize the risk of loan default and to value loans, so that returns could be considered more appropriated to cover loan losses. Kosmidou and Pasiouras (2008) got a positive relationship between loan loss provisions and profitability.

\section{LNDEPO- Market Share}

This variable is included in the regression model to measure the banks' market share calculated as a natural logarithm of total banks' deposits. In other words, it is used as a proxy variable for the network embedded. Chu \& Lim (1998) described that large banks may attract more deposits and loan transactions whereas the smaller banks with smaller deposits might have to support purchasing funds which are costlier (Lim \& Randhawa, 2005). Lim \& Randhawa (2005) also pointed out that small banks have attained higher efficiency levels compared to their large counterparts because, with their smaller deposit base, they transform fewer deposits into loans.

\section{GDP- Economic Activity}

To measure economic activity within an economy, GDP is the most used macroeconomic indicators. It is expected that many factors related to the demand and supply affected by GDP such as deposits and loans for banks. Bikker \& Hu (2002) mentioned that there is a positive relationship between GDP growth and the profitability of banks because favorable macroeconomic conditions within the country create a good environment for the banking sector. If GDP declines, it will affect very badly on bank performance. So, GDP growth is expected to have a positive effect on the performance of banks.

\section{Inflation}

Inflation is commonly used as an external profitability indicator, impacting both banks' costs and revenues. Inflation can have negative effects on banks' profitability when overhead costs are higher than inflation rates. A fully anticipated inflation rate increases profit because banks can change interest rates adequately in order to increase revenue. An unintended shift could, on the other hand, increase costs due to inefficient rate changes. It depends very much on whether the impact of inflation is predicted or not. Dietrich \& Wanzenried (2014) and Ahokpossi (2013) found a positive relationship, while Goddard et al. (2011) indicated an insignificant relationship between profitability and inflation.

\section{Methodology}

We used OLS (ordinary least square) method to estimate the determinants of banks' profitability. To examine the profits' determinants of Bangladeshi, we estimate a linear regression model of the following form:

$y_{j t}=\delta_{t}+\alpha_{i t} X_{i j t}+\varepsilon_{j t}$

where $\mathrm{j}=$ an individual bank; $\mathrm{t}=$ year; $y_{i t}=$ profitability of bank $\mathrm{i}$ at time $\mathrm{t} ; X_{i}=$ internal factors of a banks' profitability; $\varepsilon_{j t}=$ random variable error term. 
By extending equation (1), the regression model is formulated below:

$y_{i t}=\delta_{0}+\alpha_{1} S I Z E_{j t}+\alpha_{2} C I R_{j t}+\alpha_{3} C A P_{j t}+\alpha_{4} L O A N_{j t}$
$+\alpha_{5} D E P_{j t}+\alpha_{6} L L P_{j t}+\alpha_{7} M S_{j t}+\alpha_{8} G D P_{j t}+\alpha_{9} I N F_{j t}+\varepsilon_{j t}$

where $y_{i t}$ is the profitability of bank I at time t; ROA and ROE are the two alternative performance indicators for the bank $\mathrm{j}$ at time $\mathrm{t}$.

Equation (2) is estimated through a fixed effects regression analysis and we use the least square method to a fixed-effects model. White (1980) transformation is applied to control for cross-section heteroskedasticity of the variables. With Hausman test (Baltagi, 2001), the option of a fixed effects model rather than a random effects one has been verified. The Breusch-Pagan test is also used to check the residual heteroskedasticity.

\section{EMPIRICAL RESULTS AND DISCUSSION}

\section{Descriptive Statistics}

Table 2 reports the results of descriptive statistics for all the variables. On average, the Bangladeshi banks included in our sample exhibit a ROA of 0.011134 over the entire period from 2014 to 2018. The amount of ROA ranges from 0.000100 to 0.038100 , and the standard deviation for ROA is 0.005251 . The banks in our sample display an ROE of 0.117160 on average and a standard deviation of 0.042776 . On the other hand, a wide range of variation is evident regarding some independent variables. CIR (cost to income ratio) ranges from 0.158200 to 69.41000 and its standard deviation is 5.931160. In average capital ratio (CAP) is 0.097103 and the standard deviation is 0.044283 .

As of loan ratio (LOAN), and deposit ratio (DEP) shows a mean of 0.653135 and 0.768085 , respectively. Regarding standard deviation, SIZE and LNDEPO are higher than other independent variables after CIR. The mean of macroeconomic variables such as GDP and inflation (INF) was 6.9 and $6 \%$ respectively.

\section{Table 2. Descriptive statistics}

\begin{tabular}{|l|l|l|l|l|l|}
\hline & \multicolumn{1}{|c|}{ Mean } & \multicolumn{1}{c|}{ Median } & \multicolumn{1}{c|}{ Maximum } & \multicolumn{1}{c|}{ Minimum } & \multicolumn{1}{c|}{ Std. Dev. } \\
\hline ROA & 0.011134 & 0.0108 & 0.0381 & 0.0001 & 0.005251 \\
\hline ROE & 0.11716 & 0.1155 & 0.2216 & 0.0013 & 0.042776 \\
\hline SIZE & 11.8785 & 12.19121 & 12.91713 & 9.530248 & 0.858268 \\
\hline CIR & 1.021579 & 0.4886 & 69.41 & 0.1582 & 5.93116 \\
\hline CAP & 0.097103 & 0.084396 & 0.325168 & 0.049634 & 0.044283 \\
\hline LOAN & 0.653135 & 0.677249 & 0.767305 & 0.060183 & 0.093969 \\
\hline DEP & 0.768085 & 0.786497 & 0.860423 & 0.080945 & 0.082592 \\
\hline LLP & 0.013731 & 0.010449 & 0.165776 & 0 & 0.018036 \\
\hline LNDEPO & 11.60169 & 11.92407 & 12.66098 & 9.045348 & 0.886951 \\
\hline GDP & 0.06982 & 0.071 & 0.079 & 0.0601 & 0.006425 \\
\hline INF & 0.06004 & 0.0568 & 0.0701 & 0.0556 & 0.005486 \\
\hline
\end{tabular}




\section{Regression Analysis}

Before the regression analysis, the data set applied in the model is tested by using the correlation matrix. Table 3 presents the correlation coefficient between the explanatory variables used in this study. The result shows that in general, the correlation between independent variables is not strong, meaning that multicollinearity problem is not severe. Kennedy (2008) mentioned that the multicollinearity can be considered a problem when the correlation is above 0.80 . However, it is worth noting that the correlations between SIZE and LNDEPO variables are relatively high.

The regression results focusing on the relationship between bank profitability and the independent variables are presented in Table 4. Adjusted $R^{2}$ value indicates exactness of additional predictor variables with statistical decrement. As the difference between $R^{2}$ and adjusted $R^{2}$ values is not high in each model, it can be said that the correlation between dependent and independent variables is at an acceptable level. The values of the F-statistic are significant, patronizing the validity and the firmness of the model used in our study. The explanatory power of the models is close, as the adjusted $R^{2}$ value ranges from 0.472993 to 0.505783 . The highest value for the adjusted $R^{2},(0.505783)$ results in Model 2 which evidence that about 51 percent of the variation of dependent variable ROE is explained by the independent variables included in the model.

The result shows that size has a positive and significant relationship with both ROA and ROE. The coefficient is significant in all cases, meaning that larger banks succeed more than smaller ones in obtaining a higher ROA and ROE. Many researchers noted that by increasing the size of banking assets, little cost savings can be achieved (Berger et al., 1987). Hauner (2005) documented that a positive relationship between size and profitability is related to the economies of scale. As banks having huge amounts of assets generally control a larger portion of the market, improving profits through the allocation of fixed costs over a larger volume of services, a potential cause might happen towards market power (Hauner, 2005). According to Smirlock (1985), larger banks can benefit from higher product and loan diversification opportunities. As the unit costs of smaller banks are likely to be higher than large-scale banks, their profitability ratios are expected to be lower.

In the case of cost to income ratio (CIR), it is found that there is a positive association between the operating the cost-income ratio and profitability although it is not statistically significant.

The results also reveal that capital ratio (CAP) is positively correlated with profitability in both models, indicating that well-capitalized banks experience higher returns, the chances of going bankrupt

Table 3. Correlation matrix

\begin{tabular}{|l|l|l|l|l|l|l|l|l|l|l|l|l|}
\hline & ROA & ROE & SIZE & CIR & CAP & LOAN & DEP & LLP & LNDEPO & GDP & INF \\
\hline ROA & 1 & 0.60 & -0.34 & 0.01 & 0.35 & -0.15 & -0.04 & -0.08 & -0.33 & -0.09 & 0.01 \\
\hline ROE & & 1 & 0.21 & 0.00 & -0.35 & 0.20 & 0.11 & -0.03 & 0.21 & 0.05 & -0.08 \\
\hline SIZE & & & 1 & 0.06 & -0.75 & 0.46 & 0.02 & 0.11 & 0.97 & 0.25 & -0.23 \\
\hline CIR & & & & 1 & 0.01 & -0.01 & 0.04 & 0.00 & 0.07 & -0.05 & 0.02 \\
\hline CAP & & & & & 1 & -0.48 & -0.27 & -0.08 & -0.76 & -0.27 & 0.27 \\
\hline LOAN & & & & & & 1 & 0.21 & -0.49 & 0.48 & 0.47 & -0.47 \\
\hline DEP & & & & & & & 1 & -0.05 & 0.24 & 0.10 & -0.14 \\
\hline LLP & & & & & & & & 1 & 0.10 & -0.04 & 0.08 \\
\hline LNDEPO & & & & & & & & & 1 & 0.27 & -0.26 \\
\hline GDP & & & & & & & & & & 1 & -0.92 \\
\hline INF & & & & & & & & & & & 1 \\
\hline
\end{tabular}


Table 4. Regression results

\begin{tabular}{|c|c|c|c|c|}
\hline \multicolumn{5}{|c|}{ Model 1 - Dependent variable: ROA } \\
\hline Variable & Coefficient & Std. Error & t-Statistic & Prob. \\
\hline Constant & -0.161362 & 0.060897 & -2.649751 & 0.0094 \\
\hline SIZE & 0.047495 & 0.010027 & 4.736884 & $0.0000^{* * *}$ \\
\hline CIR & $1.26 \mathrm{E}-06$ & $6.26 \mathrm{E}-05$ & 0.020094 & 0.9840 \\
\hline CAP & 0.106401 & 0.031643 & 3.362517 & $0.0011^{* * *}$ \\
\hline LOAN & 0.006321 & 0.009059 & 0.697751 & 0.4870 \\
\hline DEP & 0.120418 & 0.027915 & 4.313792 & $0.0000^{* * *}$ \\
\hline LLP & 0.018821 & 0.031704 & 0.593658 & 0.5541 \\
\hline LNDEPO & -0.038517 & 0.009551 & -4.032907 & $0.0001 * * *$ \\
\hline GDP & -0.459832 & 0.202782 & -2.267614 & $0.0255^{* *}$ \\
\hline INF & -0.331723 & 0.157926 & -2.100499 & $0.0382 * *$ \\
\hline R-squared & 0.610644 & & & \\
\hline Adjusted R-squared & 0.472993 & & & \\
\hline F-statistic & 4.436176 & & & \\
\hline Durbin-Watson stat & 2.035518 & & & \\
\hline \multicolumn{5}{|c|}{ Model 2 - Dependent variable: ROE } \\
\hline Variable & Coefficient & Std. Error & t-Statistic & Prob. \\
\hline Constant & -1.670407 & 0.480359 & -3.477415 & 0.0008 \\
\hline SIZE & 0.326172 & 0.079091 & 4.124010 & $0.0001 * * *$ \\
\hline CIR & 0.000122 & 0.000494 & 0.247043 & 0.8054 \\
\hline CAP & 0.543947 & 0.249604 & 2.179237 & $0.0317 * *$ \\
\hline LOAN & 0.089106 & 0.071455 & 1.247026 & 0.2153 \\
\hline DEP & 0.658458 & 0.220192 & 2.990387 & $0.0035^{* * *}$ \\
\hline LLP & 0.318143 & 0.250082 & 1.272155 & 0.2063 \\
\hline LNDEPO & -0.203409 & 0.075337 & -2.699994 & $0.0082 * * *$ \\
\hline GDP & -4.079679 & 1.599556 & -2.550507 & $0.0123^{* *}$ \\
\hline INF & -1.056041 & 1.245727 & -0.847731 & 0.3986 \\
\hline R-squared & 0.634869 & & & \\
\hline Adjusted R-squared & 0.505783 & & & \\
\hline F-statistic & 4.918162 & & & \\
\hline Durbin-Watson stat & 1.917854 & & & \\
\hline
\end{tabular}

Notes: ${ }^{* * *},{ }^{* *}$, and ${ }^{*}$ indicate significant at $1 \%, 5 \%$, and $10 \%$ respectively

are low, and their cost of funding is reducing. This finding is consistent with previous studies of Berger (1995), Pasiouras \& Kosmidou (2007), Demirguc-Kunt \& Huizinga (1999), Goddard et al. (2004), Staikouras \& Wood (2004), and Sufian \& Chong (2008). Results of the regression analysis document that loan ratio (LOAN) shows a positive but insignificant relationship with ROA and $\mathrm{ROE}$, indicating that more loans raise the chances of achieving more profitability. But the effect is not conclusive as the relationship is insignificant. 
Furthermore, regression results suggest that deposit ratio (DEP) has a significant impact on bank profitability (in both ROA and ROE). It refers that more deposits improve the lending capacity and as the demand for lending increased, even profitability enlarged. Bangladeshi banks with higher lending growth rates are more profitable than slowly lending banks. The result is similar to some previous studies such as Al-Jerrah et al. (2010) and Saeed (2014). Turning to the other explanatory variable, the result of loan loss provisions to total gross loans ratio (LLP) indicates that it does not have a significant impact on bank profitability as measured by ROA and ROE. It seems that the impact of network embeddedness (LNDEPO) has a negative and strong impact on bank profitability. Ahokpossi (2013) documented that market share can negatively influence profitability if highly market-powered banks intentionally lower their prices to deport other contenders.

Another important result of the analysis is that there is a negative relationship between GDP and the profitability of the banks. Tan \& Floros (2012) also found a negative relationship between these two variables by explaining that rapid economic development lowers barriers to bank entry, the resulting rise in competition decreased the profitability of the banks. We also regard inflation, as a macroeconomic variable and the result has shown that it has no big effect on ROE. However, it has a major negative impact on the ROA, which means that banks have not expected inflation during the duration analyzed.

\section{CONCLUDING REMARKS AND POLICY IMPLICATIONS}

This study focuses on defining the possible banking and macroeconomic determinants of bank profitability in Bangladesh. 27 commercial banks in Bangladesh are considered from 2014 to 2018. Instead of a random effect model, fixed effect model is used to generate six bank determinants and two macroeconomic variables. The outcome from regression analysis indicates that size is the principal determinant of Bangladeshi banks' profits, supporting the argument that large banks have taken advantage of economies of scale (Short, 1979; Bourke, 1989; Molyneux \& Thorton, 1992, Athanasoglou et al., 2008; Flamini et al., 2009). The results also reveal that capital strength, measured by equity to total assets, is one of the major determinants of bank profitability in Bangladesh. In the case of external financing, well-capitalized banks face lower barriers and this advantage drives a bank into higher profitability (Bourke, 1989; Demirguc-Kunt \& Huizinga 1999; Goddard et al., 2004). Regression analysis also reveals that the impact of deposits (DEP) on ROE and ROA is positive and significant at $1 \%$ significant level. The result is consistent with the argument that increased deposits may benefits banks by generating more profits, while limited deposits may negatively influence their sustainability (Lee \& Hsieh, 2013). Furthermore, market share (LNDEPO) also shows a negative and significant impact on banks' profitability in Bangladesh. It may happen if high market-powered banks drop their rates in order to evict other rivals (Ahokpossi, 2013). On the other hand, a higher ratio of net loans to total assets (LOAN)) may certainly lead to a higher level of profits although its not significant. From the macroeconomic perspective, economic growth and inflation seem to affect banks' profitability negatively. It may occur as the expansion of economic growth minimize the barriers to bank entry which increases the competition, thus diminished banks' profitability (Tan \& Floros, 2012).

The results illustrate interesting insights into the features and practices of successful commercial Bangladeshi banks regarding profitability. By reviewing the results, some suggestions may be useful for banks' management, policymakers, and shareholders. Bangladeshi banks should try to reinforce their capital structures and enhancement of their assets because these attempts will secure the reliance of potential investors; banks will have the opportunity to collect less expensive capital. Additionally, relatively profitable banks will be able to maximize risk-adjusted returns on investment and to sustain stable and competitive advantages is a crucial element to safeguard the competitiveness of the Bangladeshi banking sector. To attain efficiency, profitability, and competitiveness, identifying the profitability determinants of successful banks will be crucial as it can assist to formulate policies 
for intensifying and maintaining the strength and stability of the banking sector in Bangladesh. The contribution of this study is twofold. First, the results provide comprehensive new insights into the reasons that determine the profitability of commercial banks in Bangladesh. Second, the study could be a support for Bangladeshi banks, government, policymakers, stakeholders, investors in their decisionmaking process and especially could be important for the global institutional investors looking for profitable investment opportunities in Bangladesh banking sector.

Finally, future research could include more factors such as regulation indicators, taxation, and exchange rates, as well as indicators of the quality of the offered services. Another extension could be the examination of differences in the determinants of profitability between small and large or high and low profitability banks. Because there is a limited number of top banks in Bangladesh, medium banks could be included in the analysis to increase the sample and a longer time period could be considered to obtain more accurate results. 


\section{REFERENCES}

Abreu, M., \& Mendes, V. (2001, May). Commercial bank interest margins and profitability: evidence for some EU countries. In Pan-European Conference Jointly Organised by the IEFS-UK \& University of Macedonia Economic \& Social Sciences, Thessaloniki, Greece, May (Vol. 34, No. 2, pp. 17-20). Academic Press.

Adelopo, I., Lloydking, R., \& Tauringana, V. (2018). Determinants of bank profitability before, during, and after the financial crisis. International Journal of Managerial Finance.

Ahokpossi, M. C. (2013). Determinants of bank interest margins in Sub-Saharan Africa (No. 13-34). International Monetary Fund.

Akhavein, J. D., Berger, A. N., \& Humphrey, D. B. (1997). The effects of megamergers on efficiency and prices: Evidence from a bank profit function. Review of Industrial Organization, 12(1), 95-139. doi:10.1023/A:1007760924829

Al-Jarrah, I. M., Ziadat, K. N., \& El-Rimawi, S. Y. (2010). The determinants of the Jordanian's banks profitability: A cointegration approach. Jordan Journal of Business Administration, 6(2), 247-261.

Altunbaş, Y., Gardener, E. P., Molyneux, P., \& Moore, B. (2001). Efficiency in European banking. European Economic Review, 45(10), 1931-1955. doi:10.1016/S0014-2921(00)00091-X

Angbazo, L. (1997). Commercial bank net interest margins, default risk, interest-rate risk, and off-balance sheet banking. Journal of Banking \& Finance, 21(1), 55-87. doi:10.1016/S0378-4266(96)00025-8

Athanasoglou, P. P., Brissimis, S. N., \& Delis, M. D. (2008). Bank-specific, industry-specific and macroeconomic determinants of bank profitability. Journal of International Financial Markets, Institutions and Money, 18(2), 121-136. doi:10.1016/j.intfin.2006.07.001

Baltagi, B. (2001). Econometric Analysis of Panel Data. John Wiley \& Sons.

Bashir, A. H. M. (2003). Determinants of profitability in Islamic banks: Some evidence from the Middle East. Islamic Economic Studies, 11(1).

Batten, J., \& Vo, X. V. (2019). Determinants of bank profitability-Evidence from Vietnam. Emerging Markets Finance \& Trade, 55(6), 1417-1428. doi:10.1080/1540496X.2018.1524326

Ben Naceur, S. (2003, November). The determinants of the Tunisian banking industry profitability: Panel evidence 1980-2000. Paper présenté à la 11ème Conférence de l'Economic Research Forum (ERF), Marrakech. www. erf. org

Berger, A. N. (1995). The profit-structure relationship in banking-Tests of market-power and efficient-structure hypotheses. Journal of Money, Credit and Banking, 27(2), 404-431. doi:10.2307/2077876

Berger, A. N., Hanweck, G. A., \& Humphrey, D. B. (1987). Competitive viability in banking: Scale, scope, and product mix economies. Journal of Monetary Economics, 20(3), 501-520. doi:10.1016/0304-3932(87)90039-0

Bikker, J. A., \& Hu, H. (2002). Cyclical patterns in profits, provisioning and lending of banks and procyclicality of the new Basel capital requirements. PSL Quarterly Review, 55(221).

Bourke, P. (1989). Concentration and other determinants of bank profitability in Europe, North America and Australia. Journal of Banking \& Finance, 13(1), 65-79. doi:10.1016/0378-4266(89)90020-4

Chu, S. F., \& Lim, G. H. (1998). Share performance and profit efficiency of banks in an oligopolistic market: Evidence from Singapore. Journal of Multinational Financial Management, 8(2-3), 155-168. doi:10.1016/ S1042-444X(98)00025-5

Demirgüç-Kunt, A., \& Huizinga, H. (1999). Determinants of commercial bank interest margins and profitability: Some international evidence. The World Bank Economic Review, 13(2), 379-408. doi:10.1093/wber/13.2.379

Dietrich, A., \& Wanzenried, G. (2014). The determinants of commercial banking profitability in low-, middle-, and high-income countries. The Quarterly Review of Economics and Finance, 54(3), 337-354. doi:10.1016/j. qref.2014.03.001 
Flamini, V., McDonald, C. A., \& Schumacher, L. B. (2009). The determinants of commercial bank profitability in Sub-Saharan Africa. IMF Working Papers, 1-30.

Goddard, J., Liu, H., Molyneux, P., \& Wilson, J. O. (2011). The persistence of bank profit. Journal of Banking \& Finance, 35(11), 2881-2890. doi:10.1016/j.jbankfin.2011.03.015

Goddard, J., Molyneux, P., \& Wilson, J. O. (2004). The profitability of European banks: A cross-sectional and dynamic panel analysis. Manchester School, 72(3), 363-381. doi:10.1111/j.1467-9957.2004.00397.x

Golin, J. (2001). The Bank Credit Analysis Handbook: A Guide for Analysts, Bankers and Investors. John Wiley and Sons.

Haslem, J. A. (1968). A statistical analysis of the relative profitability of commercial banks. The Journal of Finance, 23(1), 167-176. doi:10.1111/j.1540-6261.1968.tb03004.x

Hassan, M. K., \& Bashir, A. H. M. (2003, December). Determinants of Islamic banking profitability. In 10th ERF annual conference, Morocco (Vol. 7, pp. 2-31). Academic Press.

Hauner, D. (2005). Explaining efficiency differences among large German and Austrian banks. Applied Economics, 37(9), 969-980. doi:10.1080/00036840500081820

Hess, K., \& Francis, G. (2004). Cost income ratio benchmarking in banking: A case study. Benchmarking, 11(3), 303-319. doi:10.1108/14635770410538772

Jiang, G., Tang, N., Law, E., \& Sze, A. (2003). The profitability of the banking sector in Hong Kong. Hong Kong Monetary Authority Quarterly Bulletin, 3(36), 5-14.

Kosmidou, K., Tanna, S., \& Pasiouras, F. (2005, September). Determinants of profitability of domestic UK commercial banks: panel evidence from the period 1995-2002. In Money Macro and Finance (MMF) Research Group Conference (Vol. 45, pp. 1-27). Academic Press.

Lee, C. C., \& Hsieh, M. F. (2013). The impact of bank capital on profitability and risk in Asian banking. Journal of International Money and Finance, 32, 251-281. doi:10.1016/j.jimonfin.2012.04.013

Lim, G. H., \& Randhawa, D. S. (2005). Competition, liberalization and efficiency: Evidence from a two-stage banking model on banks in Hong Kong and Singapore. Managerial Finance, 31(1), 52-77. doi:10.1108/03074350510769479

Menicucci, E., \& Paolucci, G. (2016). The determinants of bank profitability: empirical evidence from European banking sector. Journal of Financial Reporting and Accounting.

Miller, S. M., \& Noulas, A. G. (1997). Portfolio mix and large-bank profitability in the USA. Applied Economics, 29(4), 505-512. doi:10.1080/000368497326994

Molyneux, P., \& Thornton, J. (1992). Determinants of European bank profitability: A note. Journal of Banking \& Finance, 16(6), 1173-1178. doi:10.1016/0378-4266(92)90065-8

Naceur, S. B., \& Goaied, M. (2001). The determinants of the Tunisian deposit banks' performance. Applied Financial Economics, 11(3), 317-319. doi:10.1080/096031001300138717

Neely, M. C., \& Wheelock, D. C. (1997). Why does bank performance vary across states? Review - Federal Reserve Bank of St. Louis, 79(2), 27.

Pasiouras, F., \& Kosmidou, K. (2007). Factors influencing the profitability of domestic and foreign commercial banks in the European Union. Research in International Business and Finance, 21(2), 222-237. doi:10.1016/j. ribaf.2006.03.007

Rajan, R. G., \& Zingales, L. (1995). What do we know about capital structure? Some evidence from international data. The Journal of Finance, 50(5), 1421-1460. doi:10.1111/j.1540-6261.1995.tb05184.x

Revel, J. (1979). Inflation and Financial Institutions. The Financial Times Ltd.

Rivard, R. J., \& Thomas, C. R. (1997). The effect of interstate banking on large bank holding company profitability and risk. Journal of Economics and Business, 49(1), 61-76. doi:10.1016/S0148-6195(96)00041-0 
Saeed, M. S. (2014). Bank-related, industry-related and macroeconomic factors affecting bank profitability: A case of the United Kingdom. Research Journal of Finance and Accounting, 5(2), 42-50.

Saona Hoffmann, P. R. (2011). Determinants of the Profitability of the US Banking Industry. Academic Press.

Short, B. K. (1979). The relation between commercial bank profit rates and banking concentration in Canada, Western Europe, and Japan. Journal of Banking \& Finance, 3(3), 209-219. doi:10.1016/0378-4266(79)90016-5

Smirlock, M. (1985). Evidence on the (non) relationship between concentration and profitability in banking. Journal of Money, Credit and Banking, 17(1), 69-83. doi:10.2307/1992507

Staikouras, C. K., \& Wood, G. E. (2004). The determinants of European bank profitability. International Business \& Economics Research Journal, 3(6).

Sufian, F. (2009). Factors influencing bank profitability in a developing economy: Empirical evidence from Malaysia. Global Business Review, 10(2), 225-241. doi:10.1177/097215090901000206

Sufian, F., \& Chong, R. R. (2008). Determinants of bank profitability in a developing economy: Empirical evidence from the Philippines. Asian Academy of Management Journal of Accounting \& Finance, 4(2).

Tan, Y., \& Floros, C. (2012). Bank profitability and inflation: The case of China. Journal of Economic Studies (Glasgow, Scotland), 39(6), 675-696. doi:10.1108/01443581211274610

White, H. (1980). A heteroskedasticity-consistent covariance matrix estimator and a direct test for heteroskedasticity. Econometrica, 48(4), 817-838. doi:10.2307/1912934 